\title{
Economic analysis of dairy and fish farming based integrated model in Punjab
}

\author{
Singh, N., ${ }^{1}$ Singh, V. P., ${ }^{2} \bowtie$ Kaur, I., ${ }^{3}$ Gupta, R. K., ${ }^{4}$
}

Received: 28.09.2020

Revised: 13.12.2020

Accepted: 13.01.2021

\begin{abstract}
The present study has been carried out in South-Western and Central agro climatic regions of Punjab state for studying the cost-returns and marketing pattern of dairy and fish farming based integrated model. It was observed from the study that the net returns from crop farming was $₹ \mathbf{1 , 6 5 , 8 5 2}$ per farm per year, whereas the net returns on per acre basis were found to be $₹ \mathbf{3 2 , 3 2 8}$ per acre per year. Further, the net returns from dairy farming were found to be $₹ 44,928$ per farm per year and $₹ \mathbf{7 8 , 8 2 2}$ per acre per year. From fish farming, net returns were observed to be $₹ 2,47,396$ per farm per annum and $₹ 84,725$ per acre per year. Total profitability of the crop-dairy-fish farming integrated model was observed to be $₹ 4,58,176$ per farm per annum, and net returns per acre from this model were $₹ 53,030$ per year. Hence, it may be inferred that dairy and fish farming are more profitable as compared to crops and when adopted in an integrated manner along with crops, can enhance the overall profitability of the farm by efficient utilisation of farm waste products and byproducts. At the same time, there is need of creating awareness among the farmers regarding the importance of dairy and fish farming based integrated models, so that they can adopt these types of models for enhancing their income levels.
\end{abstract}

Key Words: Fixed cost, integrated model, marketing pattern, marketed surplus, net returns, variable cost

\section{Introduction}

The livestock sector is an integral component of agriculture and the rural economy in India (Bhutiani and Ahamad, 2019). Agriculture and livestock sector are interdependent in such a way that it ensures sustainable livelihood to a large component of the rural population. For the small land holders and landless rural poor, the livestock sector is an important source of subsidiary income and livelihood. Presently, in India, the contribution livestock sector is 28.40 per cent of agricultural gross domestic product (GDP) (Anonymous, 2019a). Punjab is primarily an agricultural state, where the mainstay of the rural masses is agriculture and allied enterprises including the livestock sector. While the contribution of crop GDP is on the decrease, the percentage share of livestock GDP in agricultural GDP is continuously increasing and has reached 37.65 per cent in 201718 from 29.60 per cent in 2000-01. The GDP from

\section{Author's Address}

${ }_{1,2,3}$ Department of Dairy Economics and Business Management, College of Dairy Science \& Technology

${ }^{4}$ Department of Livestock Production Management, College of Veterinary Science,

Guru Angad Dev Veterinary and Animal Sciences University, Ludhiana-141004

E-mail.: dhindsavp@gmail.com livestock and fisheries sectors is increasing at the rate of 5.71 per cent and 6.74 per cent per year in the present decade (Anonymous, 2018). According to Singh and Joshi, 2008, dairy farming has emerged as an important allied enterprise which supplements the income of farmers, especially marginal and small ones. It contributes more than eighty per cent of the total livestock value of output in the state of Punjab (Anonymous 2019b). Similarly, other livestock enterprises like goat, pig and fish farming are remunerative enterprises providing a good source of income and employment compared to mono-culture of paddywheat crop rotation. There is immense potential to exploit further the contribution of dairy, piggery, goat farming and fisheries sector in the state. For the much-needed diversification of agriculture sector in Punjab state, the integration of livestock farming with crop farming can provide a viable option. For providing gainful employment to lakhs of rural people, the livestock sector is an important sector. Most often, the livestock sector is the only source of cash returns for subsistence farmers and for ensuring purchasing power in the case of crop failure. To sustain the steady agricultural growth and to reduce rural poverty, the rapid growth of the 
livestock sector is most desirable. Growth in livestock has more potential to reduce poverty than a similar growth in the crop sector (Mellor, 2004). According to Srinika et al. (2017), the adoption of the integrated farming system instead of any individual crop-livestock enterprising will not only sustain the livelihood but also provided food security especially at the small and marginal scale of farming. Singh and Kumari (2017) highlighted the importance of the livestock sector in doubling farmers income by 2022 and brought out that India has the largest livestock resources when compared to other countries. It is a boon for the small farmers who own a small piece of land. The focus of the present government is on doubling farmers' income by 2022. Only the livestock component would provide the facilitating inputs to enhance the income of farm families within a short period of five years in a synergistic mode (Ponnusamy and Devi, 2017). The present study will be one of its kind in this direction and will provide useful information to policy planners, future researchers and other concerned in the livestock sector.

\section{Material and Methods}

The present study has been carried out during the agricultural year 2018-19 in two agro-climatic regions of Punjab state viz. South Western region (comprising of Bathinda, Sri Muktsar Sahib, Mansa, Faridkot, Firozpur and Fazilka districts with a total geographical area of 1488 thousand ha (29.57 per cent) and Central region (comprising of Amritsar, Gurdaspur, Tarn Taran, Jalandhar, Kapurthala, Ludhiana, Barnala, Moga, Sangrur, Patiala and Fatehgarh Sahib districts with a total geographical area of 2725 thousand ha (54.14 per cent). Two districts, one from each zone, were selected randomly for a detailed economic study of dairy and fish-based integrated models. The selected districts were Muktsar from South Western Zone and Ludhiana from Central Zone. A sample of 12 farmers of dairy and fish farming based integrated models were selected randomly for detailed primary study. The sample farmers included those farmers who were rearing dairy animals and practising fish farming along with crops in an integrated manner.

\section{Concepts used}

\section{Variable cost}

The variable cost is that component of the total cost which vary with the level of production. The variable cost of cultivation of crops included value of diesel used, seed, manure, fertilisers, plant protection chemicals, irrigation, human labour etc. and interest on working capital. The prices prevailing in the market in respective areas were considered for calculating above items of variable cost. The imputed value of family labour was considered while calculating the total labour expenditure. Interest on variable cost was taken @ 4 per cent for half the crop period. The actual cost of home-produced green fodder was considered for dairy production. While working out the feed and fodder cost, prevailing market rates in the particular region were taken into consideration. For calculating the labour expenditure, the local prevailing wage rates were taken into account. Items of miscellaneous expenditure were the cost of water, electricity charges and repairs.

\section{Fixed cost}

Fixed cost comprised of depreciation and interest on investment. Depreciation was worked out by using the straight-line method, and further, the interest on fixed investment was worked out @10 per cent per annum.

\section{Gross returns}

The gross return has been worked out by multiplying total product with the unit price considering income from the main product as well as by-products. The prices actually prevailing in the market were considered.

\section{Net Returns:}

The net returns have been worked out as the difference between the gross returns and total cost (fixed + variable cost).

\section{Benefit-cost ratio}

The benefit-cost ratio has been worked out as gross returns divided by total cost. For a profitable business, the benefit-cost ratio should be more than one.

\section{Marketed surplus}

It is the quantity of the products which the farmer producer actually sells in the market irrespective of his requirements for a home, farm and other purposes. 


\section{Results and Discussion}

Cost and returns from Crop-Dairy-Fish farming integrated model in Punjab

Cost and returns from the crop-dairy-fish farming integrated model in Punjab have been presented in Table 1-4 in this section. Average landholding in this model was found to be 8.64 acres out of which 5.25 acres were under wheat and 0.47 acres under fodder crops in rabi season and 5.05 acres under paddy and 0.67 acres under fodder crops in Kharif season. The remaining area of 2.92 acres was under fish farming. In this integrated model, dung from the dairy animals was used for fertilising the fish pond resulting in saving of ₹ 2500-3000 per acre and for increasing the land fertility for crop farming. The waste/surplus water from the fish pond, which is rich in nutrients, was used for irrigating the field crops, hence cutting down the cost of fertilisation of crops to the extent of ' 1000 2000 per acre. The fodder grown in the fields and wheat straw produced were used for feeding the dairy animals, hence saving the cost of purchased fodder. A perusal of Table 1 revealed that net returns from crop farming, i.e. paddy-wheat crop rotation were ₹ $1,65,852$ per farm per year, whereas the net returns on per acre basis were found to be 32,328 per acre per year.

Regarding cost returns from dairy farming in this model, it was revealed from Table 2 that total cost of dairy farming per lactation was ₹ $3,50,626$ per farm out of which fixed cost was ₹ 69,637 (19.86 per cent) and the variable cost was ₹ $2,80,989$ (80.14 per cent). The main component of the variable cost was concentrate feed (42.83 per cent) followed by fodder expenditure (30.42 per cent). The gross returns were found to be $₹ 4,08,479$ per farm, and net returns were ₹ 57,853 per farm on per lactation basis. The net returns on per year basis were found to be ₹ 44,928 per farm. The benefitcost ratio was worked out at 1.16. Further, after converting the annual net returns to per acre basis by considering the average area under fodder crops, the net returns were found to be ₹ 78,822 per acre per annum which were quite high as compared to per acre net returns of ₹ 32,328 per year from paddy-wheat crop rotation. Regarding cost returns from fish farming in this model, it was revealed from Table 3 that total annual cost of fish production was ₹ $1,34,762$ per farm out of which fixed cost was ₹ 20,753 (15.40 per cent) and the variable cost was ₹ $1,14,009$ ( 84.60 per cent). The main component of the variable cost was supplementary feed (35.42 per cent) followed by labour charges (23.16 per cent). The gross returns from the sale of fish were found to be ₹ 3,82,158 per farm per annum, and net returns were ₹ $2,47,396$ per farm per annum. The benefit-cost ratio was as high as 2.84 , indicating high profitability of the fish farming enterprise. Further, on per acre basis, the net returns were found to be ₹ 84,725 per acre per annum which were quite high as compared to per acre net returns of ₹ 32,328 from paddywheat crop rotation. Total profitability of the cropdairy-fish farming integrated model was observed to be ₹ 4,58,176 per farm per annum (Table 4), and on per acre basis, net returns from this model as a whole were ₹ 53,030 per acre per annum. Hence, it may be concluded from the above discussion that fish farming contributes a major share in the farm income of crop-dairy-fish farming integrated model and helps in curtailing the cost of cultivation of crop farming through the usage of excess/surplus fish pond water for irrigation purposes. Further, dairy farming can play an important role in providing additional income and curtailing the cost of fish and crop production by utilisation of dairy waste as a source of nutrients.

\section{Marketing pattern of dairy farming in Crop-} Dairy-fish farming integrated model

Various parameters of the marketing pattern of dairy farming in the crop-dairy-fish farming integrated model have been represented in Table 5. A total of twelve farmers were engaged in dairy farming in this model. A perusal of the table brought out that marketed surplus in milk was as high as 94.70 per cent. The sale of the milk was mainly in the village ( 58.34 per cent) followed by sale from the farm (41.66per cent). The milk was sold mainly to the cooperative society (58.34 per cent) followed by direct sale to the consumers (41.66 per cent). A majority of the farmers (58.34 per cent) sold milk on fat/SNF basis followed by 41.66 per cent farmers selling on flat volume basis directly to the consumers. The mode of payment was cash (66.67 per cent) as well as both cash and kind (33.33 per cent). All the farmers received the payments within a period of fifteen days. Regarding market information, it was observed that 66.67 per cent of the farmers have access to market 
Singh et al.

Table 1. Cost and returns from crop farming in Crop-Dairy-Fish farming integrated model in Punjab, 201819 (₹/year)

\begin{tabular}{|l|l|l|l|l|l|}
\hline SN & Crop & Total cost & Gross returns & Net returns & $\begin{array}{l}\text { Net returns per } \\
\text { acre }\end{array}$ \\
\hline i. & Wheat $(5.25$ acres $)$ & $1,030,83$ & $1,71,187$ & 68,104 & 12,972 \\
\hline ii. & Paddy $(5.05$ acres $)$ & $1,04,560$ & $2,02,308$ & 97,748 & 19,356 \\
\hline & Total & $2,07,643$ & $3,73,495$ & $1,65,852$ & 32,328 \\
\hline
\end{tabular}

Table 2. Cost and returns from dairy farming in Crop-Dairy-Fish farming integrated model in Punjab.

\begin{tabular}{|l|l|l|}
\hline SN & Particulars & Amount (₹ Per farm/lactation) \\
\hline A. & Fixed cost & 25014 \\
\hline i & Depreciation & 44623 \\
\hline ii. & Interest on capital investment & $\mathbf{6 9 , 6 3 7}$ \\
\hline & Total fixed cost & \multicolumn{2}{|l|}{} \\
\hline B. & Variable cost & 85471 \\
\hline i. & Fodder & 120336 \\
\hline ii. & Concentrate feed & 880 \\
\hline iii. & Mineral mixture & 8079 \\
\hline iv. & Veterinary expenses & 28842 \\
\hline v. & Labour charges & 37381 \\
\hline vi. & Miscellaneous expenses & $\mathbf{2 , 8 0 , 9 8 9}$ \\
\hline & Total variable cost & $\mathbf{3 , 5 0 , 6 2 6}$ \\
\hline C. & Total cost (A+B) & \multicolumn{2}{|l|}{} \\
\hline D. & Returns & $\mathbf{3 , 9 3 , 0 4 9}$ \\
\hline i. & Returns from milk & $\mathbf{1 5 , 4 3 0}$ \\
\hline ii. & Appreciation of calves & $\mathbf{4 , 0 8 , 4 7 9}$ \\
\hline E. & Gross returns & $\mathbf{5 7 , 8 5 3}$ \\
\hline F. & Net returns & 1.16 \\
\hline & Benefit-cost ratio & 44,928 \\
\hline & Net returns per year & $\mathbf{7 8 , 8 2 2}$ \\
\hline & Net returns per acre & \multicolumn{2}{|l|}{} \\
\hline
\end{tabular}

Table 3. Cost and returns from fish farming in Crop-Dairy-Fish farming integrated model in Punjab (₹/year)

\begin{tabular}{|l|l|l|}
\hline SN & Particulars & Amount INR (₹per farm) \\
\hline A. & Fixed cost & 18762 \\
\hline i. & Interest on capital & 1991 \\
\hline ii. & Depreciation & $\mathbf{2 0 , 7 5 3}$ \\
\hline & Total Fixed cost & 17850 \\
\hline B. & Variable cost & 3938 \\
\hline i. & Fish seed & 40381 \\
\hline ii. & Manure / Fertilizer & 26400 \\
\hline iii. & Supplementary feed & 25440 \\
\hline iv. & Labour charges & $\mathbf{1 , 1 4 , 0 0 9}$ \\
\hline iv. & Miscellaneous expenses & $\mathbf{1 , 3 4 , 7 6 2}$ \\
\hline & Total Variable cost & $\mathbf{3 , 8 2 , 1 5 8}$ \\
\hline C. & Total cost ( A+B) & $\mathbf{2 , 4 7 , 3 9 6}$ \\
\hline D. & Gross returns & 84,725 \\
\hline E. & Net returns & 2.84 \\
\hline F. & Net returns/acre & \\
\hline G. & Benefit-cost ratio &
\end{tabular}


Economic analysis of dairy and fish farming

Table 4. Overall profitability of Crop-Dairy-Fish farming integrated model in Punjab, 2018-19 (₹/year).

\begin{tabular}{|l|l|l|}
\hline SN & Particulars & Amount INR (₹ per farm) \\
\hline i. & Net returns from crop farming & $1,65,852$ \\
\hline ii. & Net returns from dairy farming & 44,928 \\
\hline iii. & Net returns from fish farming & $2,47,396$ \\
\hline iv. & Total net returns & $4,58,176$ \\
\hline v. & Net returns/acre & 53,030 \\
\hline
\end{tabular}

Table 5. Marketing pattern of dairy farming in Crop-Dairy-Fish farming integrated model in Punjab, 201819

\begin{tabular}{|c|c|c|c|c|}
\hline SN & Parameter & Particulars & Value & $\%$ \\
\hline \multirow[t]{3}{*}{ i } & \multirow{3}{*}{$\begin{array}{l}\text { Marketed Surplus } \\
\text { (Litres) }\end{array}$} & Average annual production & 7268 & - \\
\hline & & Consumed at home & 385 & - \\
\hline & & Marketed Surplus & 6883 & 94.70 \\
\hline \multirow[t]{2}{*}{ ii } & \multirow{2}{*}{$\begin{array}{l}\text { Sale } \\
\text { (No. of farmers) }\end{array}$} & From farm & 5 & 41.66 \\
\hline & & In the village & 7 & 58.34 \\
\hline \multirow[t]{2}{*}{ iii } & \multirow{2}{*}{$\begin{array}{l}\text { Sold to } \\
\text { (No. of farmers) }\end{array}$} & Consumer & 5 & 41.66 \\
\hline & & Cooperative society & 7 & 58.34 \\
\hline \multirow[t]{2}{*}{ iv } & \multirow{2}{*}{$\begin{array}{l}\text { Sold on which basis } \\
\text { (No. of farmers) }\end{array}$} & Fat/SNF basis & 7 & 58.34 \\
\hline & & Flat volume basis & 5 & 41.66 \\
\hline \multirow[t]{3}{*}{$\mathrm{v}$} & \multirow{3}{*}{$\begin{array}{l}\text { Mode of payment } \\
\text { (No. of farmers) }\end{array}$} & Cash & 8 & 66.67 \\
\hline & & Kind & - & - \\
\hline & & Both & 4 & 33.33 \\
\hline \multirow[t]{2}{*}{ vi } & \multirow{2}{*}{$\begin{array}{l}\text { Frequency of payment } \\
\text { (No. of farmers) }\end{array}$} & Immediate & - & - \\
\hline & & Within 15 days & 12 & 100.00 \\
\hline \multirow[t]{2}{*}{ vii } & \multirow{2}{*}{$\begin{array}{l}\text { Market information } \\
\text { (No. of farmers) }\end{array}$} & Yes & 8 & 66.67 \\
\hline & & No & 4 & 33.33 \\
\hline \multirow[t]{4}{*}{ viii } & \multirow{4}{*}{$\begin{array}{l}\text { Source of market } \\
\text { information } \\
\text { (No. of farmers, multiple } \\
\text { responses) }\end{array}$} & Friends & 6 & 50.00 \\
\hline & & Print media & 5 & 41.66 \\
\hline & & Electronic media & 2 & 16.67 \\
\hline & & Farmers fairs & 4 & 33.33 \\
\hline
\end{tabular}

information and further, the major source of such the winter months (₹108/kg) and lowest during market information were friends (50.00 per cent) summer months (₹ 82/kg). The frequency of sale of and print media (41.66 per cent).

Marketing pattern of fish farming in Crop- The mode of payment was mainly cash. Regarding Dairy-fish farming integrated model

A total of twelve farmers were engaged in fish farming in this model. A perusal of Table 6 brought out that marketed surplus of fish was as high as 99.91 per cent. The sale of the fish was mainly from the farm, and the fish was sold mainly through the pre-harvest contractors. All the farmers sold the fish produce on a weight basis. The sale price of fish was not uniform as it varied according to season. The highest prices were observed during the frequency of payment, a majority of the farmers (58.33 per cent) got immediate payment followed by 25.00 farmers getting payment within fifteen days and 16.67 per cent farmers receiving payment within three months. With regard to the market information, fifty per cent fish farmers have access to market information and further, the major source of such market information were friends (fifty per cent farmers' response) followed by electronic media with fifty per cent reporting this source. 
Table 6. Marketing pattern of fish farming in Crop-Dairy-Fish farming integrated model in Punjab, $2018-19$

\begin{tabular}{|c|c|c|c|c|}
\hline SN & Parameter & Particulars & Value & $\%$ \\
\hline \multirow[t]{3}{*}{$\mathrm{i}$} & \multirow{3}{*}{$\begin{array}{l}\text { Marketed Surplus } \\
(\mathrm{Kgs})\end{array}$} & Average annual production & 4044 & - \\
\hline & & Fish consumed at home & 3.60 & - \\
\hline & & Marketed Surplus & 4040.4 & 99.91 \\
\hline \multirow[t]{2}{*}{ ii } & \multirow{2}{*}{$\begin{array}{l}\text { Sale } \\
\text { (No. of farmers) }\end{array}$} & From farm & 12 & 100.00 \\
\hline & & In market & - & - \\
\hline \multirow[t]{3}{*}{ iii } & \multirow{3}{*}{$\begin{array}{l}\text { Sold to } \\
\text { (No. of farmers) }\end{array}$} & Pre-harvest contractor & 12 & 100.00 \\
\hline & & Consumer & - & - \\
\hline & & Others & - & - \\
\hline \multirow[t]{2}{*}{ iv } & \multirow{2}{*}{$\begin{array}{l}\text { Sold on which base } \\
\text { (No. of farmers) }\end{array}$} & Age & - & - \\
\hline & & Weight & 12 & 100.00 \\
\hline \multirow[t]{6}{*}{$\mathrm{v}$} & \multirow{6}{*}{$\begin{array}{l}\text { Sale price } \\
\text { (Per Kg) }\end{array}$} & Uniform & - & - \\
\hline & & According to demand & 12 & 100.00 \\
\hline & & Highest price during & December & - \\
\hline & & Highest price (') & 108 & - \\
\hline & & Lowest price during & June & - \\
\hline & & Lowest price (') & 82 & - \\
\hline \multirow[t]{3}{*}{ vi } & \multirow{3}{*}{$\begin{array}{l}\text { Frequency of sale } \\
\text { (No. of farmers) }\end{array}$} & Regular & - & - \\
\hline & & Monthly & 2 & 16.67 \\
\hline & & Quarterly & 10 & 82.33 \\
\hline \multirow[t]{3}{*}{ vii } & \multirow{3}{*}{$\begin{array}{l}\text { Mode of payment } \\
\text { (No. of farmers) }\end{array}$} & Cash & 12 & 100.00 \\
\hline & & Kind & - & - \\
\hline & & Both & - & - \\
\hline \multirow[t]{5}{*}{ viii } & \multirow{5}{*}{$\begin{array}{l}\text { Frequency of payment } \\
\text { (No. of farmers) }\end{array}$} & Immediate & 7 & 58.33 \\
\hline & & 15 days & 3 & 25.00 \\
\hline & & 3 months & 2 & 16.67 \\
\hline & & 6 months & - & - \\
\hline & & $>6$ months & - & - \\
\hline \multirow[t]{2}{*}{ ix } & \multirow{2}{*}{$\begin{array}{l}\text { Market information } \\
\text { (No. of farmers) }\end{array}$} & Yes & 6 & 50.00 \\
\hline & & No & 6 & 50.00 \\
\hline \multirow[t]{4}{*}{$\mathrm{x}$} & \multirow{4}{*}{$\begin{array}{l}\text { Source of market } \\
\text { information } \\
\text { (No. of farmers, multiple } \\
\text { responses) }\end{array}$} & Friends & 6 & 50.00 \\
\hline & & Print Media & 5 & 41.66 \\
\hline & & Electronic media & 6 & 50.00 \\
\hline & & Farmers fairs & 4 & 33.33 \\
\hline
\end{tabular}

\section{Conclusion}

Total profitability of the crop-dairy-fish farming integrated model was observed to be $4,58,176$ per farm per annum, and net returns per acre from this model were 53, 030 per year. The overall profitability per acre has increased by integrating the farming system with dairy and fish farming rather than growing traditional crops alone. Regarding marketing pattern of dairy farming, it was observed that marketed surplus of milk was as high as 94.70 per cent. The milk was sold mainly to the cooperative society followed by direct sale to the consumers. The mode of payment was cash as well as both cash and kind. All the farmers received the payments within a period of fifteen days. Regarding market information, it was observed that 66.67 per cent of the farmers have access to market information, and further, the major source of such 
market information were friends and print media. Further, the marketed surplus of fish was as high as 99.91 per cent. The sale of the fish was mainly from the farm, and the fish was sold mainly through the pre-harvest contractors. The mode of payment was mainly cash. Regarding the frequency of payment, a majority of the farmers ( 58.33 per cent) got immediate payment followed by 25.00 farmers getting payment within fifteen days and 16.67 per cent farmers getting payment within three months. With regard to the market information, fifty per cent fish farmers have access to market information and further, the major source of such market information were friends and electronic media. Dairy and fish farming are more profitable as compared to crops and when adopted in an integrated manner along with crops, can enhance the overall profitability of the farm by efficient utilisation of farm waste products and by-products. The main concern here is the lack of awareness among the farmers regarding the importance and

\section{References}

Anonymous. 2018. Statistical Abstract of Punjab. Economic Advisor to Government, Economic and Statistical Organisation, Chandigarh.

Anonymous. 2019a. Basic Animal Husbandry Statistics Department of Animal Husbandry, Dairying and Fisheries, Ministry of Agriculture, Government of India, New Delhi.

Anonymous. 2019b. State-wise and item-wise value of output from agriculture, forestry and fishing. National Statistical Office, Ministry of Statistics and Programme Implementation, Government of India, New Delhi.

Bhutiani, R. and Ahamad, F. 2019. A case study on changing pattern of agriculture and related factors at Najibabad region of Bijnor, India. In: Contaminants in Agriculture and Environment: Health Risks and Remediation. Edited by Vinod Kumar, Rohitashw Kumar, Jogendra Singh and Pankaj Kumar. DOI: 10.26832/AESA-2019-CAE-0158018, pp 237-247. higher profitability of integrated models. Hence, there is a need for creating awareness among the farmers regarding the importance of dairy and fish farming based integrated models.

\section{Acknowledgement}

The paper has been culled from the thesis entitled "Examining the profitability and marketing pattern of various livestock-based integrated models in Punjab " submitted by first author Navjot Singh to Guru Angad Dev Veterinary and Animal Sciences University, Ludhiana-141004 during February 2020 under the guidance of second author Dr Varinder Pal Singh. The authors are thankful to the ViceChancellor, GADVAU, Ludhiana and Dean, College of Dairy Science and Technology, GADVASU, Ludhiana for providing necessary infrastructure and other support required for completion of the study.

Mellor, J. 2004. Agricultural growth and poverty reduction: The rapidly increasing role of small holder livestock, in V. Ahuja (ed) Livestock and Livelihoods: Challenges and opportunities for Asia in the emerging market environment, NDDB, Anand.

Ponnusamy, K. and Devi, M. K. 2017. Impact of integrated farming system approach on doubling farmers' income. Agricultural Economics Research Review, 30: 233-40.

Singh, M. and Joshi, A. S. 2008. Economic analysis of crop production and dairy farming on marginal and small farms in Punjab. Agricultural Economics Research Review, 21: 251-257.

Singh, P. and Kumari, B. 2017. Importance of Livestock Sector in Doubling Farmers Income by 2022. Indian Journal of Economics and Development, 13: 136-140.

Srinika, M., Kumari, R. V., Suhasini, K. and Bhave, M. H. V. 2017. Adoption of integrated farming system-an approach for doubling small and marginal farmers' income. Indian Journal of Economics and Development, 13: 443-447. 